\title{
An Exploration into the Practices of the EFL Teachers of Humbo Tebela Secondary and Preparatory School Teach Writing Through Content Based Instruction
}

\author{
Tesfaye Buche Bosha Temesgen Tora Kacho Tegegn Tefera Zula \\ College of Social Science and Humanities Department of English Language and Literature Wolaita Sodo \\ University, Sodo Ethiopia
}

\begin{abstract}
The main purpose of this study was an exploration into the perception of Humbo Tebela Secondary and Preparatory School EFL teachers in teaching writing through Content-Based Instruction. Descriptive survey research design was employed for the current study. The researcher selected all the fourteen EFL teachers without sampling because of their limited number. On the other hand, 360 students selected by using simple random sampling technique by lottery method. The data gathering instruments used for study were: interview, questionnaire and classroom observation. The interview data were taped and transcribed into textual form. The classroom observation data were noted to analyze data. The close-ended questions of the questionnaire were treated in number and percentage using SPSS. Qualitative analysis was carried out to analyze the data gathered via open-ended items of the questionnaire. Finally, the results of statistical analysis were described verbatim. From the analysis of data, different findings were obtained. The study portrayed EFL teachers of Humbo Tebela Secondary and Preparatory School teachers' practice on teaching writing through content-based instruction seemed below the standard that means majority of EFL teachers do not use content-based instruction when teaching writing. Most of the time they were rushing to cover the portion rather than focusing on content knowledge of students; some of EFL teachers and students have misconception about content-based instruction. Therefore, positive perception is not only mandatory for its implementation and EFL teachers of the school properly implement writing skills using CBI so it needs continuous awareness creation activity is paramount.
\end{abstract}

Keywords: Practice, Writing Skills and Content-Based Instruction

DOI: $10.7176 / \mathrm{JLLL} / 72-03$

Publication date:October $31^{\text {st }} 2020$

\section{Introduction}

According to Stern (1983), all of the aforementioned methods have their own assumptions about English language and how it is learned. They have also their own objectives, principles, features, materials, techniques, roles assigned to students and teachers and activities. Context, students' maturity and their level of target language, learning style and strategies of language learning (Stern, 1983), determine the use of a given method. Each of these methods has its own weak sides and strong sides, which means advantages and disadvantages. Hence, there is no best method without weakness.

Content-based instruction (CBI) is defined as "the teaching of content or information in the language being learned with little or no direct or explicit effort to teach the language itself separately from the content being taught" (Krahnke, as cited in Richards and Rodgers, 2001:204). It is distinguished from other methods by its focus on the concurrent learning of specific language content and related to language skills (Brinton et al., 2011; Cenoz and Zarobe, 2015; Genesee and Lindholm-Leary, 2013; Tedick and Wesely, 2015). Its chief concern is "the integration of content learning with language teaching aims" (p: 9). However, some CBI models prioritize language learning over content learning, other models prioritize mastery of content over language acquisition and others seek to find a balance between language and content (Brinton et al., 2011). What these models all have in common, however, is that CBI focuses on using the target language instead of learning about the target language (Hernandez, 2003).

Content-based instruction is becoming increasingly popular in general education as well as in second and foreign language teaching. It has a number of characteristics, which make it particularly effective in language instruction. According to Stoller (1997), one of its most important benefits is that it lends itself to the natural teaching of the four language skills. For example, within content-based instruction, students are required to read authentic reading materials, to interpret and evaluate the information contained in them, to cooperate, so that they can respond either orally or in writing. Such an approach also takes it for granted that writing follows from listening and reading and thus "requires students to synthesize facts and ideas from multiple sources as preparation for writing" (Stoller, 1997: 29). The findings of empirical research show that students find it easier to learn materials which are thematically organized (Singer, 1990), and that meaningful information, a principal feature of contentbased instruction, can lead to deeper processing (Anderson, 1990). In addition, content-based classes usually stimulate students' interest and engagement, leading to enhanced motivation.

Bearing these all essence of $\mathrm{CBI}$ in mind, this study wished-for to assess teachers' practice of teaching writing 
through content based instruction in Humbo Tebela Secondary and Preparatory School.

\section{Statement of the Problem}

English Language is being used as the medium of instruction in senior secondary and tertiary levels of education in Ethiopia. Hence, learners are expected to have adequate proficiency in using the language. This is because the learners' skills in using the language are highly determinant factor for their academic success (Atkins et al., 1995). Therefore, students should develop their English language proficiency by learning it through appropriate methodology.

One of the current assumptions in EFL pedagogy is accepting writing as a process (Reid, 1993). This approach promotes the engaging of students in regular classroom and extensive practice of writing through generating ideas, drafting their paragraphs/essays and checking their writing individually or in groups (Hedge, 2005 and Squire, 1979). However, EFL teachers usually implement the product approach to teaching writing and expect learners to produce pieces of written products for evaluation (Reid, 1993). This kind of approach does not replicate real-life writing; rather, it is meant for learning, not for communication. This hindered the development of students' writing skills for years $(\mathrm{p} ; 117)$.

Under the more general rubric of Communicative Language Teaching (CLT), the CBI is a learner-centered method (Littlewood, 1981). As to him, students learn through doing and are actively engaged in the learning process. In this approach, learners are expected to express their ideas with great concern and frequently (Littlewood, 1981). In addition, Brinton, Snow, and Wesche (1989) stated that learners are exposed to a considerable amount of language through stimulating content in CBI. Learners also explore interesting content and are engaged in appropriate language-dependent activities in CBI. It supports contextualized learning; i.e., learners are taught useful language that is embedded within relevant discourse contexts rather than as isolated language fragments (Brinton, 1989). Hence, students make greater connections with the language and what they already know and complex information that is delivered through real life context for the students to grasp ideas well and leads students to intrinsic motivation (Brinton, Snow and Wesche, 1989: 7).

\section{Research Design and Methodology \\ 3.1. Research Design}

Descriptive survey research design is non-experimental because it deals with the relationships among nonmanipulated variables (Zoltan, 2007). It is more appropriate to assess teachers' practice of teaching writing through content-based instruction. Therefore, descriptive survey research design is employed for this study. Finally, the researchers employed both quantitative and qualitative methods of data analysis.

\subsection{Setting and Participants of the Study}

This study was conducted at Humbo Tebela Secondary and Preparatory School. The reason behind selection of this school was its proximity, which helped the researcher to manage time, resources and money effectively.

\subsection{Sampling Techniques}

Among fourteen EFL teachers, the researcher used all the fourteen EFL teachers using convenience-sampling technique because of all of them were convenient for this study. On the other hand, among 4,783 students, 360 students were selected through simple random sampling technique by using a lottery method.

\subsection{Data Collection Instruments}

This research was conducted to understand the practice of teaching writing through content-based instruction. To collect valuable and relevant data, three instruments of data collection namely interview, questionnaire and classroom observation were used. Before gathering data for the main study, the instruments were pilot tested in order to ensure validity and reliability.

\subsection{Methods of Data Analysis}

The data gathered through questionnaire, classroom observation and interview were analyzed using both quantitative and qualitative methods of data analysis. The interviews data were transcribed and transformed into textual data. Analysis was done primarily with thematic expression of using the qualitative approach. First, the questionnaire was checked whether it was complete. Then, it was grouped into three main parts according to the research questions. After that, the close-ended questions of the questionnaire treated in number and percentage using SPSS version 20. Qualitative analysis carried out to analyze the data gathered via open-ended items of the questionnaire. Finally, four English language teachers were observed two times while teaching writing through content-based instruction and the observation data were analyzed by using thematic expressions focus on pre-set observation checklist. 


\section{Analysis, Interpretation and Discussion of Results}

4.1 English Language Teachers' Practice on Teaching Writing through Content-based Instruction Having good or positive perception or attitude on teaching writing through content-based instruction, to put it into practice is not enough by itself. Besides, teachers should practically provide content-based instruction in writing classroom. Accordingly, teachers were interviewed whether or not English language teachers provide contentbased instruction in writing classroom. Furthermore, teachers were asked how EFL teachers of Humbo Tebela Secondary and Preparatory School teach writing through content-based instruction. Their response is described in this section.

4.1.1Teachers' Response of Items on how they teach Writing via CBI

Eight selected teachers were interviewed with five items (see Appendix-A for interview item) and replied the following responses.

Teachers were asked to tell whether the technique that they use for teaching writing is content-based instruction. One of the interviewed teacher B mentioned that he was rushing to cover the portion rather giving due attention to each skill. Besides, Teacher D said that most of the time, he teach grammar and vocabulary and he rationalized that forty minute is not much to teach writing using different techniques rather than rushing to cover other portion. Teacher $\mathrm{C}$ and $\mathrm{F}$ pointed out almost similar ideas that writing skill get less attention because most of the time examinations focus solely on grammatical part rather than other skills including writing skill. Teacher $\mathrm{H}$ justified that teaching writing through content-based instruction takes time and he conceive it as huge task put it into practice.

On the other hand, Teacher E replied that he provides varieties of tasks while teaching writing through content-based instruction. Similar teacher pointed that he motivates students to participate in writing task, provides opportunities to students and realization of a lesson that means relating lessons with a real context. Besides, Teacher $\mathrm{A}$ and Teacher $\mathrm{G}$ replied almost a similar idea that operating theme-based instruction is mandatory to teach writing through content-based instruction. This means that subject matter knowledge is very important technique to implement teaching writing through content-based instruction. In a general manner of speaking, the interview result disclosed that majority of teachers have wrong conception about the techniques of teaching writing through content-based instruction. This shows that almost all teachers have gap in providing different techniques of teaching writing even they have misconception on content-based instruction itself.

Teachers were asked to answer how they contextualize the lesson of writing when they teach their students through content-based instruction. In response to this, Teacher A, E and G replied almost similar ideas that they contextualize the lesson while teaching writing by using different tactics such as motivating when teaching writing, providing varieties of tasks specifically assigning them in a group and giving group, pair and team activities in order to realize the content into their real life situation.

Again, Teacher B replied that he simply writes writing activities on the blackboard and reminds them the day lesson which means he did not give due attention to contextualize the writing lesson. Teacher $\mathrm{F}$ and $\mathrm{D}$ reported almost similar ideas that teaching material is not suitable to teach writing through content-based instruction. Similar teachers expressed that textbook is suitable to contextualize other skills, specifically grammar than writing skill. This is because there is shortage of activities that is designed in grade 9-12 English text syllabuses. Teacher $\mathrm{C}$ and $\mathrm{H}$ replied almost similar ideas that students were very low in writing skill which means they were unable to participate writing tasks. This and other factor determines them to contextualize the writing through content-based instruction. Based on the above data, it is possible to say that majority of teachers do not contextualize the lesson what is expected from them in their writing lesson. This shows that EFL teachers low in contextualizing writing lesson through content-based instruction.

Teachers were interviewed to answer how they make contents of teaching writing interesting for learners while teaching writing via content-based instruction. In response to this, Teacher A replied that he makes contents of teaching writing interesting for learners in their writing through using different tactics such as providing feedback whether it makes content of writing interesting or not for his students which means through provision of feedback. Additionally, Teacher B, C and D reported almost similar ideas that they were motivating their students to make content of writing interesting while teaching writing via content-based instruction. Teacher E put in his part he relates writing lesson with students' real life situations. Teacher F and Teacher G reported almost similar ideas that making writing content interesting while teaching writing is a challenging task. Because it depends on different factors such as content by itself, students' ability, textbook and class size and other factors hamper making content of writing interesting for learners.

However, teachers of English language were not observed when they make a content of teaching writing interesting for learners while teaching writing through content-based instruction. Nevertheless, it is possible to say that based on their response, almost all teachers make contents of teaching writing interesting for learners while teaching writing by means of content-based instruction. As a researcher observation, result teachers of English language make content of teaching writing interesting for learners while teaching writing during content-based instruction was seems below their response that means their theory mismatch with making it into practice. 
Teachers were asked how they make tasks of teaching writing varied while implementing content-based instruction. In response to this, Teacher $\mathrm{C}$ replied that he makes tasks of teaching writing varied during implementing content-based instruction. Each teacher was interviewed how he/she makes tasks varied. In reply to this, Teacher A and B reported almost related ideas that makes tasks in teaching writing varied by using different tasks such as sentence level writing, paragraph level writing and essay level writing within a single writing lesson. Teacher D rationalized that giving different task by itself not enough to make writing lesson varied while implementing content-based instruction.

On the other hand, Teacher E responded that he did not make tasks of writing varied while implementing content-based instruction. Similar teacher replied that implementing content-based instruction during writing by itself is not effectively implemented before making tasks of writing varied. This was because of many factors such as shortage of time, students' level of doing tasks; textbook is not suitable to make writing tasks in teaching writing via content-based instruction, large class size, and lack of interest for both teachers and students, shortage of acculturated practice implementing content-based instruction when teaching writing. Teacher $\mathrm{F}$ and $\mathrm{H}$ forwarded that methodology by itself has its own limitation which means teaching method of teaching writing is one direction rather than participative. These is because of rushing to cover portion rather than making tasks of teaching writing varied while implementing content based instruction. From the above data, it is possible to deduce that majority of teachers of English language do not make tasks of teaching writing varied while implementing content-based instruction.

This was confirmed during classroom observation that shows teachers were not observed making tasks of teaching writing varied while implementing content-based instruction. It reveals that teachers of English language have gap in making tasks of teaching writing varied while implementing content-based instruction. Even positively responded three teachers have their own gap that indicates they were asked how make it varied. In response to this, they were giving different tasks such as sentence, paragraph and essay level writing. This shows that they have misconception on making teaching writing varied while implementing content-based instruction and it means out of this context. The last teacher $\mathrm{H}$ reported that to make writing lesson varied, it needs some awareness creation activity such as training, development and seminaries that is designed by experts. This shows that almost all teachers have misconception as well as gap in making tasks of teaching writing varied when implementing contentbased instruction. Thus, all teachers of English language have gap in making tasks varied during implementing content-based instruction.

Teachers were interviewed to answerer whether they have any opinion that they want to further explain about the whole process of teaching writing via content-based instruction here at Tebela Secondary and Preparatory School. In response to this, Teacher A responded that the whole process of teaching writing by means of contentbased instruction at Humbo Tebela context seems below the expected level in practical engagement. Teacher B and $\mathrm{C}$ pointed almost related ideas that most of the time teachers of English language give due attention to exam centered, rule based and teacher centered method of teaching rather than communicative language teaching approach, specifically content-based instruction.

Teacher D explained that writing skills also get less attention in his school context. This is because their assessment also centres on grammar and reading comprehension. Teacher $\mathrm{E}$ also said that students have problem in writing ability and they are poor in vocabulary. Teacher F and Teacher G replied that there is a lack of commitment on effectively use content-based instruction during writing skill. Large class size and students' level of performance, as a result, they do not alleviate a cultured method of teaching and rushing to cover portion. On the other hand, Teacher $\mathrm{H}$ said that the process of teaching writing through content-based instruction seems good which means he effectively provides writing using content-based instruction but not almost all teachers were observed when teaching writing through content-based instruction effectively.

Finally, almost all teachers perceived positively regarding teaching writing via content- based instruction, but they have problem in implementing it in the classroom. The interview result divulged that the whole process of teaching writing through content-based instruction seems low in practical engagement of EFL writing classroom. This implies that almost all teachers have gap in implementing content-based instruction when teaching writing. 4.1.2 Teachers' and Students' Questionnaire Result on Teachers Practice in Teaching Writing via CBI This section displays teachers practice on teaching writing through content-based instruction data collected from teachers stated as follows: 
Table 1: Teachers' Questionnaire Result on their Practice in Teaching Writing via CBI

\begin{tabular}{|c|c|c|c|c|c|c|c|c|}
\hline Items & & SA & $\mathrm{AG}$ & UD & $\mathrm{DA}$ & SDA & Tot. & Mean \\
\hline \multirow{2}{*}{$\begin{array}{l}\text { I contextualize the lesson while teaching writing } \\
\text { through content- based instruction. }\end{array}$} & $F$ & 1 & 6 & 2 & 3 & 2 & 14 & \multirow[t]{2}{*}{3.06} \\
\hline & $\%$ & 7.1 & 42.9 & 14.3 & 21.4 & 14.3 & 100 & \\
\hline \multirow{2}{*}{$\begin{array}{l}\text { I create a " theme" based instruction when teaching } \\
\text { writing skill through CBI. }\end{array}$} & $\mathrm{F}$ & 1 & 4 & 2 & 7 & - & 14 & \multirow[t]{2}{*}{2.93} \\
\hline & $\%$ & 7.1 & 28.6 & 14.3 & 50 & - & 100 & \\
\hline \multirow{2}{*}{$\begin{array}{l}\text { I select a subject of interest to learners while teaching } \\
\text { writing through CBI. }\end{array}$} & $\mathrm{F}$ & 2 & 3 & 3 & 5 & 1 & 14 & \multirow[t]{2}{*}{3.00} \\
\hline & $\%$ & 14.3 & 21.4 & 21.4 & 35.7 & 7.1 & & \\
\hline \multirow{2}{*}{$\begin{array}{l}\text { I integrate all skills when teaching writing through } \\
\text { CBI. }\end{array}$} & $\mathrm{F}$ & 3 & 1 & 6 & 3 & 1 & 14 & \multirow[t]{2}{*}{3.14} \\
\hline & $\%$ & 21.4 & 7.1 & 42.9 & 21.4 & 7.1 & 100 & \\
\hline \multirow{2}{*}{$\begin{array}{l}\text { I use authentic materials while teaching writing } \\
\text { through CBI. }\end{array}$} & $\mathrm{F}$ & 1 & 4 & - & 7 & 2 & 14 & \multirow[t]{2}{*}{2.64} \\
\hline & $\%$ & 7.1 & 28.6 & - & 50.0 & 14.3 & 100 & \\
\hline \multirow{2}{*}{$\begin{array}{l}\text { I provide opportunities for learners when teaching } \\
\text { writing via CBI. }\end{array}$} & $\mathrm{F}$ & 3 & 3 & - & 6 & 4 & 14 & \multirow[t]{2}{*}{2.57} \\
\hline & $\%$ & 21.4 & 21.4 & - & 42.9 & 28.6 & 100 & \\
\hline \multirow{2}{*}{$\begin{array}{l}\text { I give variety of tasks while teaching writing through } \\
\text { CBI. }\end{array}$} & $\mathrm{F}$ & 2 & 3 & - & 5 & 4 & 14 & \multirow[t]{2}{*}{2.57} \\
\hline & $\%$ & 14.3 & 21.4 & - & 35.7 & 28.6 & 100 & \\
\hline
\end{tabular}

Key's $\mathrm{SA}=$ strongly agree $\mathrm{AG}=\mathrm{Agree} \mathrm{UD}=\mathrm{Undecided} \mathrm{DA}=$ Disagree $\mathrm{SDA}=$ strongly disagree

It can be seen from Table 1, Item 1, 42.9\% of respondents agreed on contextualizing the lesson while teaching writing via content-based instruction. From the above data, it is possible to say that most teachers agreed on contextualizing the lesson while teaching writing through content-based instruction. $50 \%$ (see item 3 ) of teachers disagreed what they create a "theme" based instruction when teaching writing skill through content based instruction. Based on the above data, it is possible to say that half of the teachers did not create a "theme" based instruction when teaching writing through content-based instruction. 35.7\% (see item 4) of respondents disagreed on selecting a subject of interest to learners when teaching writing through content-based instruction. From the given data, it is possible to say that half of Tebela Preparatory and Secondary School teachers did not select a subject of interest to learners when teaching. This shows that there is a gap in selecting a subject of interest to learners when teaching writing via content-based instruction.

As can be seen from Table 1, Item 4, 42.9\% of teacher is undecided whether they integrate all skills when teaching writing through content-based instruction. From the given data, we can say that half of the teachers did not know how to integrate all skills by means of content-based instruction. $50 \%$ (see item 5 ) of respondents disagree that using authentic materials when teaching writing by means of content-based instruction. This shows that majority of teachers do not use authentic materials when teaching writing through content-based instruction. $42.9 \%$ (see item 6) of respondents disagree that they provide opportunities for learners while teaching via content based instruction. This indicates that half of the teachers do not provide opportunities for learners when teaching writing through content-based instruction. 35.7\% (see item 7) of respondents disagree that they give varieties of tasks while teaching writing through content-based instruction. This reveals that majority of teachers do not give varieties of tasks when teaching writing through content-based instruction. Generally speaking, the results in teacher questionnaire divulged that majority of EFL teachers of Humbo Tebela Secondary and Preparatory School have gap in implementing writing by means of content-based instruction which implies that writing skill do not get due attention and majority of them do not provide writing using content-based instruction.

Table 2: Students' Questionnaire Response on their Teachers Practice in Teaching Writing through CBI

\begin{tabular}{|l|l|l|l|l|l|l|l|l|}
\hline Items & & SA & AG & UD & DA & SDA & Tot. & Mean \\
\hline My teacher contextualizes the lessons while teaching & $\mathrm{F}$ & 145 & 133 & 51 & 16 & 15 & 360 & 4.05 \\
writing through content-based instruction. & $\%$ & 40.3 & 36.9 & 14.2 & 4.4 & 4.2 & 100 & \\
\hline $\begin{array}{l}\text { My teacher selects a subject of interest for learners } \\
\text { while teaching writing via CBI. }\end{array}$ & $\mathrm{F}$ & 97 & 107 & 75 & 57 & 24 & 360 & 3.54 \\
\cline { 2 - 8 } & $\%$ & 26.9 & 29.7 & 20.8 & 15.8 & 6.7 & 100 & \\
\hline $\begin{array}{l}\text { My teacher uses authentic materials while teaching } \\
\text { writing via CBI. }\end{array}$ & $\mathrm{F}$ & 59 & 89 & 79 & 100 & 33 & 360 & 3.11 \\
\cline { 2 - 8 } & $\%$ & 16.4 & 24.7 & 21.9 & 27.8 & 9.2 & 100 & \\
\hline $\begin{array}{l}\text { My teacher gives variety of tasks while teaching } \\
\text { writing via CBI. }\end{array}$ & $\mathrm{F}$ & 91 & 60 & 37 & 77 & 95 & 360 & 2.93 \\
\cline { 2 - 7 } & $\%$ & 25.3 & 16.7 & 10.3 & 21.4 & 26.4 & 100 \\
\cline { 2 - 6 }
\end{tabular}

Key's $\mathrm{SA}=$ strongly agree $\mathrm{AG}=\mathrm{Agree} \mathrm{UD}=$ Undecided $\mathrm{DA}=$ Disagree $\mathrm{SDA}=$ strongly disagree

As it can be seen from Table 2, Item $1,40.3 \%$ of students strongly agreed that their teacher contextualizes the lessons while teaching writing by means of content-based instruction. This show that majority of students agreed that their teacher contextualizes the lessons while teaching writing via content-based instruction. 29.7\% (see item 2) of students agreed that their teacher selects a subject of interest while teaching writing via contentbased instruction. Based on the data, it is possible to say that almost half of students agreed that their teacher selects a subject of interest for learners when teaching writing through content-based instruction. 27.8\% (see item 
3) of students disagree that their teacher uses authentic materials while teaching writing via content-based instruction. This shows that majority of English teachers do not use authentic materials when teaching writing through content-based instruction.25.3percentage (see item 4) of students strongly agreed that their teacher gives varieties of tasks when teaching writing through content-based instruction. From the above data, it is possible to say that English language teachers of Humbo Tebela Secondary and Preparatory School give varieties of tasks while teaching writing through content-based instruction.

4.1.3 Classroom Observation Result on Teachers' Practice in Teaching Writing via CBI

Eight writing lessons were observed whether EFL teachers implement teaching writing through content-based instruction. In response to this, each item was analyzed as follows:

With regard to this (see item 1), writing lessons were observed that English language teachers create a flexible environment using different stages of process writing using content-based instruction. At this time, some teachers create flexible environment using free and guided writing process. However, majority of writing lessons were not observed that EFL teachers create a flexible environment using different stages of process in content-based instruction. The classroom observation result revealed that most of English teachers do not create a flexible environment using different stages of writing process by means of content-based instruction. On the other hand (see item 2), none of writing lessons was observed that English language teachers of Humbo Tebela Secondary and Preparatory School guide learners' activity while teaching writing in various stages of writing process to final product. Most teachers do not give due attention when teaching writing, they do not give corrective feedback in writing activity rather than stages of writing process. The classroom observation result divulged that English language Teachers of Humbo Tebela Secondary and Preparatory did not guide learners' activity when teaching writing in various stages of writing process to final product by means of content-based instruction.

In Item 3, eight English language writing lessons were observed to spot whether or not English language teachers follow up the learners' activity before they pass to other stages of writing process using content-based instruction. With regard to this, none of English language writing lessons was observed when EFL teachers follow up the learners' activity before they pass to other stages of writing process by means of content-based instruction. Most EFL teachers simply write lessons on the blackboard and they do not follow up the learners' activity; however, time is not enough to follow up each student's activity before he/she pass to other stages of writing lessons.

This reveals that EFL teachers of Humbo Tebela Secondary and Preparatory School did not follow up the learners' activity before they pass to other stages of writing process using content-based instruction. On the other hand, almost all writing lessons were not observed when EFL teachers get learners practice how to solve writing problems using content-based instruction. This implies that EFL teachers of Humbo Tebela Secondary and Preparatory School poor in getting learners practice to solve writing problems by means of content-based instruction. This portrayed that most of EFL teachers of Humbo Tebela Secondary and Preparatory School teachers did not get learners' practice how to solve writing problems using content-based instruction. As it can be portrayed in Item 5, none of EFL writing lessons was observed that EFL teacher gives enough time to check writing ability of learners while teaching writing by means of content-based instruction. This depicts that not almost all EFL teachers of Humbo Tebela Secondary and Preparatory School teachers give enough time to check writing ability of learners while teaching writing through content-based instruction.

English language writing lessons were also observed to portray whether or not EFL teachers encourage peer/group correction in conjunction with other approach to feedback provision in writing tasks by using contentbased instruction. In view of that, some of EFL writing classes were observed that EFL teachers encourage peer/group correction in conjunction with other approach to feedback provision in writing tasks. Whereas, most of EFL writing lessons were not observed that EFL teacher encourages peer/group correction in conjunction with other approach to feedback provision in writing tasks by using content-based instruction. Based on the classroom observation result, it is possible to deduce that most of EFL teachers of Humbo Tebela Secondary and Preparatory School do not encourage peer/group correction in conjunction with other approach to feedback provision in writing tasks by using content-based instruction.

Again English language writing lessons were observed to portray whether or not EFL teachers use different authentic materials when teaching writing through content-based instruction. Some of EFL teachers use authentic materials when teaching writing through content-based instruction. While majority of EFL writing lessons were observed not that EFL teachers of Humbo Tebela Secondary and Preparatory School teachers use different authentic materials when teaching writing through content-based instruction. This indicates that majority of EFL teachers do not use different authentic materials while writing through content-based instruction. Therefore, Humbo Tebela Secondary and Preparatory School EFL teachers did not use different authentic materials while teaching writing skill using content-based instruction.

As it can be portrayed in Item 8, EFL writing lessons were observed to see whether or not EFL teachers make tasks varied in teaching writing through content-based instruction. With regard to this, none of EFL writing lessons was observed that EFL teachers of Humbo Tebela Secondary and Preparatory School teachers make tasks varied in teaching writing through content-based instruction. This depicts that teachers of Humbo Tebela Secondary and 
Preparatory School did not make tasks varied in teaching writing through content-based instruction. This was again confirmed through interview and questionnaire data.

EFL writing lessons were observed to see whether or not EFL teachers contextualize lessons when teaching writing through content-based instruction (see Item, 9). With regard to this, some of EFL writing lessons were observed that the EFL teachers contextualize the lessons while teaching writing through content-based instruction. This means that a very few EFL teachers contextualize the writing lessons while teaching writing using contentbased instruction. On the other hand, majority of EFL writing lessons were not observed that EFL teachers contextualize lessons when teaching writing through content- based instruction. This depicts that almost all Humbo Tebela Secondary and Preparatory School teachers did not contextualize the lessons while teaching writing through content- based instruction.

EFL writing lessons were observed to see whether or not EFL teachers make contents of teaching writing interesting for learners using content-based instruction (see Item, 10). In reply to this, a very few EFL writing lessons were observed that the EFL teachers make contents of teaching writing interesting for learners using content-based instruction. While as majority of EFL writing lessons were not observed that EFL teacher make contents of teaching writing interesting for learners using content-based instruction. From the result of observation, we can deduce that almost all EFL teachers of Humbo Tebela Secondary and Preparatory School do not make contents of teaching writing interesting for learners using content-based instruction.

In Item 11, EFL writing lessons were observed to see whether or not class size is convenient for teaching writing through content-based instruction. With regard to this, class size is large which implies 1:85 is the average of class size and this number expresses very over crowded. This portrays that classroom was not conducive for teaching writing through content-based instruction. Accordingly, class size was large and it was not convenient for teaching writing through content-based instruction. On the other hand (see item 12), EFL writing lessons were observed to see whether or not EFL teachers use content-based instruction when teaching writing. With regard to this, almost all the EFL writing classes were observed that EFL teachers use content-based instruction when teaching writing. The classroom observation result shows that all the EFL teachers use content-based instruction when teaching writing.

\subsection{Discussion of Teachers' Practice in Teaching Writing through CBI}

Concerning the $2^{\text {nd }}$ research question, "How do EFL teachers of Humbo Tebela Secondary and Preparatory School teach writing through content-based instruction?" Data were collected via questionnaire, interview and classroom observation. Accordingly, the teachers' practice on teaching writing through content-based instruction is below the standard which means majority of EFL teachers did not use content-based instruction when teaching writing. Most of the time, they were rushing to cover the portion rather than focusing on content knowledge of students even if some of EFL teachers and students have misconception about content based instruction. This reveals that EFL teachers' perception mismatch with their practice which means in their perception part they perceived positively but majority of EFL teachers did not use content-based instruction when teaching writing. This conclusion agrees with what Grabe and Stoller (1997) and Crandall (1987) noted. They stated that most of EFL teachers fail to implement content-based instruction effectively and integrate language and content properly in EFL writing classroom. Crandall (1987) pointed out that teaching methodology and technique can positively or negatively affect content instruction.

\section{Summary, Conclusions and Recommendations \\ 5.1. Summary of Major Findings}

Concerning the $2^{\text {nd }}$ research question, "How do EFL teachers of Humbo Tebela Secondary and Preparatory School teach writing through content-based instruction?" Data were collected via questionnaire, interview and classroom observation. Accordingly, as depicted through each tool, EFL teachers of Humbo Tebela Secondary and Preparatory School teachers practice on teaching writing through content-based instruction seemed below the standard, which means majority of the EFL teachers do not use content-based instruction when teaching writing. Most of the time, they were rushing to cover the portion rather than focusing on content knowledge of students even if some of EFL teachers and students have misconception about content-based instruction. This reveals that EFL teachers' perception mismatches with their practice which means in their perception part they perceived positively but majority of the EFL teachers did not use content-based instruction when teaching writing. The study revealed that teachers of Humbo Tebela Secondary and Preparatory School have gap in teaching writing through content-based instruction.

\subsection{Conclusions}

Owing to the analysis of data and the major findings of the study, the following conclusions were derived.

Having good perception or attitude on teaching writing through content-based instruction to put it into practice, is not enough by itself. Besides, teachers should practically provide content-based instruction in writing 
classroom. Accordingly, teachers were interviewed whether or not English language teachers provide contentbased instruction in writing classroom. Furthermore, teachers were asked how EFL teachers of Humbo Tebela Secondary and Preparatory School teach writing through content-based instruction.

Accordingly, as portray from interview, questionnaire and classroom observation, EFL teachers of Humbo Tebela Secondary and Preparatory School teachers' practice on teaching writing through content-based instruction seemed below the standard that means majority of EFL teachers do not use content-based instruction when teaching writing. Most of the time they were rushing to cover the portion rather than focusing on content knowledge of students; some of EFL teachers and students have misconception about content-based instruction. This reveals that EFL teachers' perception mismatch with their practice which means in their perception part they perceived positively but majority of EFL teachers do not use content-based instruction when teaching writing.

\subsection{Recommendations}

Based on the summary of the findings made and conclusions attained, the researcher would like to recommend the following:

In this study, it was stated that English language teachers' practice of teaching writing through content-based instruction needs improvements. To this end, the concerned bodies such as NGO's such as link Ethiopia, World vision Humbo ADP and government organizations should create awareness for teachers in teaching writing by means of content-based instruction and awareness creation activity is paramount.

\section{References}

Anderson, J. (1990). Cognitive psychology and its implications (3rd ed.). New York: W. H. Freeman.

Brinton, D. (2003). Content-Based Instruction. In D. Nunan (Ed.), Practical English Teaching, (p. 199-224).

Brinton, D., Snow, M. and Wesche, M. (2011). Content Based Second Language Instruction. Ann Arbor, MI: University of Michigan Press.

Brinton, D., Snow, M. and Wesche, M. (1989). Content-Based Second Language Instruction. New York: Newbury House.

Carrasquillo, L. and Rodríguez, V. (2002).Language Minority Students in the Mainstream Classroom. UK: Multilingual Matters Ltd.

Cenoz, J. and Ruiz de Zarobe, Y. (2015). Learning Through a Second or Additional Language. Content-Based Instruction and CLIL in the Twenty-First Century. Language, Culture and Curriculum.

Grabe, W. and Stoller, F. (1997). Content-Based Instruction. In Perspectives on Integrating Language and Content, (p. 5-21). New York: Longman.

Hardy, M. and Heyes, S. (1979). Beginning Psychology: A Comprehensive Introduction to Psychology (4th edition). Oxford: Oxford University Press.

Hedge, T. (2005). Writing. Oxford: Oxford University Press.

Hernandez, A. (2003). Making Content Instruction Accessible for English Language Learners. In G. Garcia (Ed.), English learners: Reaching the highest level of English literacy (p. 125-149). New York, DE: International Reading Association.

Jordan, R. (1997). English for Accademic Aurpose: A guide and Resource Book for Teachers. Cambridge: Cambridge University Press.

Littlewood, W. (1981). Communicative Language Teaching: An Introduction. Cambridge: Cambridge university press.

Ramirez, J. (1986) "Comparing Structured English Immersion and Bilingual Education: First Year Results of a National Study." American Journal of Education 95: pp.122-149.

Reid, J. (1989). English as a Second Language Composing in the Higher Education. In Empowering ESL Students, (p. 220-234). New York: Longman.

Reid, J. (1993). Teaching ESL Writing. USA: Regents Prentic Hall.

Saville, T. (1984). What really matters in second language learning for academic achievement.TESOL Quarterly, 18, pp.199-219.

Short, D. (1991). Integrating Language and Content Instruction: Strategies and Techniques. Washington, DC: national Clearinghouse for Bilingual Education.

Short, D. (1993). Assessing Integrated Language and Content Instruction. TESOL Quarterly, Vol. 27, No. 4, p, 627-656.

Short, D. (1997). Reading and Writing and ... Social Studies: Research on Integrated Language and Content in Second Language Classrooms, P. 213-232. New York: Addison- Wesley Longman.

Singer, M. (1990). Psychology of language: An introduction to sentence and discourse processing. Hillsdale, NJ: L. Erlbaum.

Smith, A. (2001). Perception and Beliefs. Philosophy and Phenomenological Research, Vol. 12. No. 2.

Snow, M., Met, M. and Genesee, F. (1989). A Conceptual Framework for the Integration of Language and Content 
in Second/Foreign Language Education. TESOL Quarterly, Vol. 23, No. 2, P. 201-217.

Snow, M. (2001). Content-Based and Immersion Models for Second and Foreign Language Teaching: Teaching English as a Second or Foreign Language (3rd ed.), (P. 303-318).

Snow, M. (1998). Trends and Issues in Content-Based Instruction. Annual Review of Applied Linguistics, Vol. 18, P. 243-267.

Squire, J. (1979). Instructional Focus and the Teaching of Writing. Aviva Freedman, Ian, Pringle and Janic Yalden (editors). Learning to Write: First Language/Second Language . London and New York: Longman Inc.

Steen, L. (1991). Reading for science literacy.Change 23(4), pp.11-19.

Stern, H. (1983). Fundamental Concepts of Language Teaching. Oxford: Oxford University Press.

Stoller, F. (2004). Content-Based Instruction. Annual Review of Applied Linguistics, Vol. 24, P. 261-283.

Stoller, F. (2002). Promoting the Acquisition of Knowledge in Content Based Course. TESOL, P. 109-123.

Stoller, F. (1997). Project Work: A Means to Promote Language Content. English Teaching Forum, 35(4), 29-37.

Sutman, F. Allen, V. and Shoemaker, F. (1986). Learning English Through Science: A Guide to Collaboration for Science Teacher, English Teachers and Teachers of English as a Second Language. Washington, DC: National Science Teachers Association.

Taguchi, E., Takayasu-Maass, M., and Gorsuch, G. (2004). Developing Reading Fluency in EFL. Reading in a Foreign Language, vol. 16, No. 2, 70-96.

Tedick, D. and Wesley, P. (2015). A Review of Research on Content-Based Foreign/Second Language Education in US K-12 Contexts. Language, Culture and Curriculum, Vol. 28, P. 25-40.

Zoltan, D. (2007). Research Methods in Applied Linguistics: Qualitative, Quantitative and Mixed Methodologies. New York: Oxford University Press. 